\title{
Primary perivascular epithelioid cell tumour (PEComa) of the liver
}

\author{
Tan To Cheung, ${ }^{1}$ Nigel Trendell-Smith, ${ }^{2}$ Ronnie T P Poon ${ }^{1}$
}

${ }^{1}$ Department of Surgery, The University of Hong Kong, Queen Mary Hospital, Hong Kong, China ${ }^{2}$ Department of Pathology, Queen Mary Hospital, Hong Kong, China

\section{Correspondence to}

Dr Tan To Cheung,

tantocheung@hotmail.com
To cite: Cheung TT, Trendell-Smith N, Poon RTP. BMJ Case Rep Published online: [please include Day Month Year] doi:10.1136/ bcr-2013-008706

\section{SUMMARY}

We present a case of a 53-year-old woman with abdominal discomfort for 6 months. The liver was enlarged. Contrast CT scan of the abdomen revealed a $10 \mathrm{~cm}$ hypervascular tumour at the right lobe of the liver. Right hepatectomy with complete excision of the tumour was achieved. Histological and immunohistochemical findings were consistent with perivascular epithelioid cell tumour. She is regularly followed up with contrast CT assessment. There is no tumour recurrence 12 months after the operation.

\section{BACKGROUND}

Primary perivascular epithelioid cell tumour (PEComa) of the liver is a very rare condition that only a few reports are present in the current literatures. It belongs to the family of mesenchymal tumours consisting of perivascular epithelioid cells. Histologically, perivascular epithelioid cells demonstrate a clear or granular cytoplasm and central round nucleus without prominent nucleoli. The presentation of the disease can present from a benign condition such as angiomyolipoma to ones that are malignant like PEComa.

We report the clinical presentation, diagnostic approach and treatment of this patient. This case highlights the diagnostic challenge and follow-up management of this disease.

\section{CASE PRESENTATION}

A 53-year-old woman presented with severe dull abdominal pain in the right upper quadrant for 6 months. She was a hepatitis B virus carrier. She did not consume alcohol and there was no history of trauma. On physical examination, there was no jaundice and pallor. There was no obvious abdominal mass or tenderness detected in her abdomen.

\section{INVESTIGATIONS}

Initial blood test showed that the haemoglobin level was $12 \mathrm{~g} / \mathrm{dL}$, the white cell count was $5 \times 10^{9} / \mathrm{L}$, the platelet count was $231 \times 10^{9} / \mathrm{L}$, the bilirubin level was $24 \mu \mathrm{mol} / \mathrm{L}$ and the $\alpha$ fetoprotein level was $4 \mathrm{ng} /$ $\mathrm{mL}$. A contrast CT of the abdomen was performed (figure 1A,B) revealing a $10 \mathrm{~cm}$ hypervascular tumour at the right lobe of the liver. The tumour showed a washout pattern in the delayed portal venous phase. In view of the tumour with a severe symptom, right hepatectomy was performed. The histopathology (figure 2) showed sheets of epithelioid and spindle-shaped cells of moderate cellularity. The spindle-shaped cells displayed a perivascular arrangement surrounding convoluted thick-walled blood vessels. Immunohistochemical stain (figure 3) of the tumour showed positivity for human melanoma black 45 (HMN45) and Melan-A. The tumour cells were negative for hepatocytic markers HEP-PAR-1, ALK1, CD21, Desmin and CD 31.

\section{DIFFERENTIAL DIAGNOSIS}

Radiological diagnosis can be challenging because there can be quantitative variation of adipose tissue, irregular vessels and smooth muscle cells. The differential diagnosis for PEComa with hypervascular presentation included vascular tumour-like hepatocellular carcinoma and haemangioma. For PEComa with more adipose cell, the differential
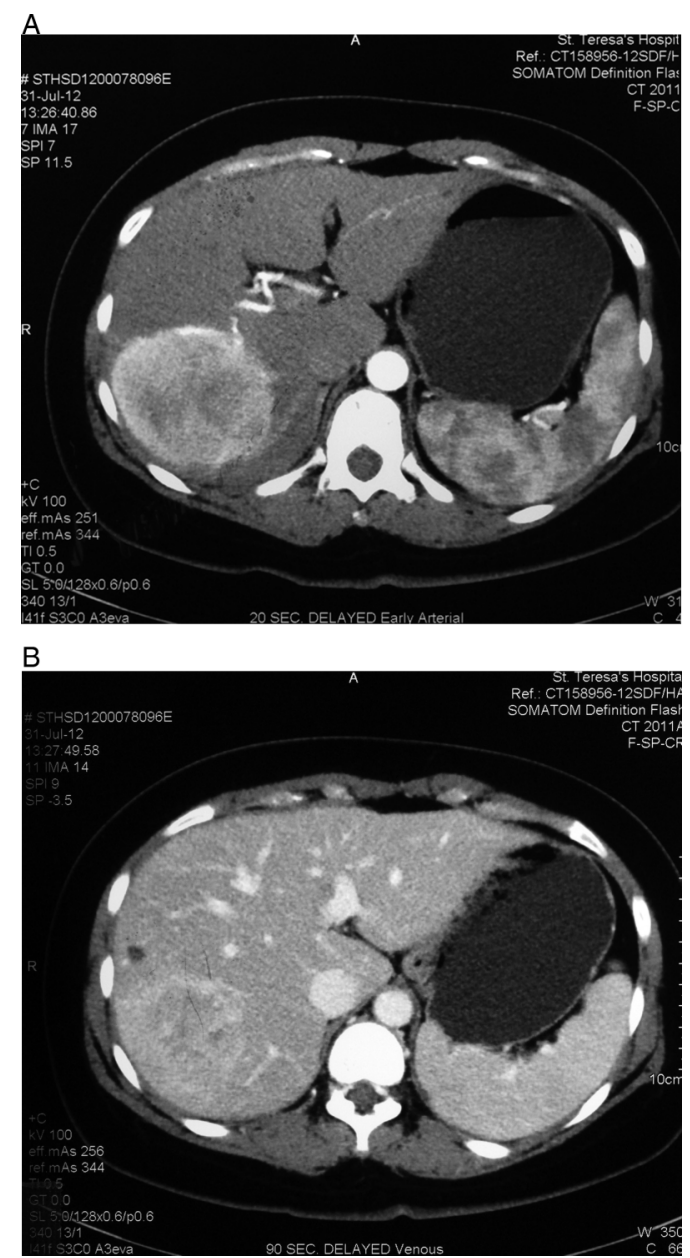

Figure 1 (A) Contrast CT scan showing a large tumour at the right lobe of the liver with arterial enhancement at postcontrast image. (B) Contrast CT scan showing vague contrast enhancement of tumour with 'washout' pattern at $90 \mathrm{~s}$ postcontrast image. 


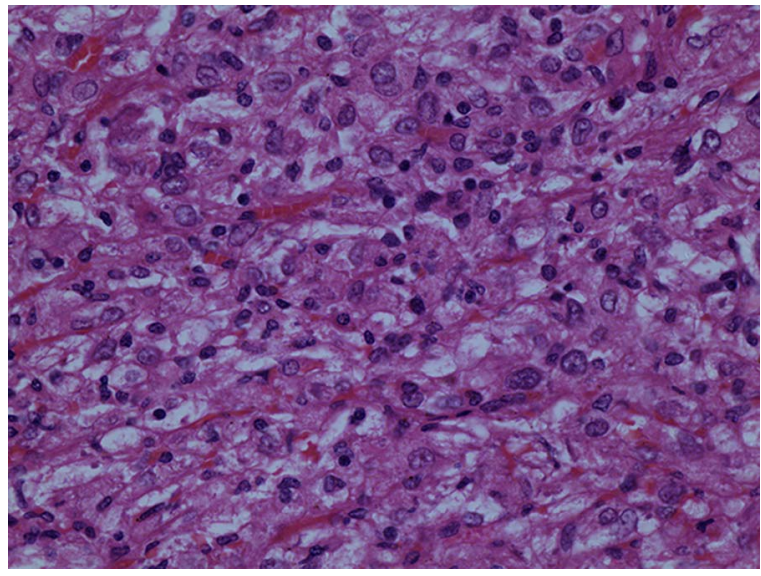

Figure 2 Histopathology showed sheets of epithelioid and spindle-shaped cells of moderate cellularity. The spindle-shaped cells displayed a perivascular arrangement surrounding convoluted thick-walled blood vessels.

diagnoses include angiomyolipoma and liposacroma. In this case, it was only after resection, the current diagnosis of PEComa could be made by immunohistochemical staining.

\section{TREATMENT}

Laparotomy was performed using right subcostal incision with sternal extension. Intraoperative ultrasonography showed a vascular tumour at the right lobe of the liver. No additional lesion was detected. Right hepatectomy was performed. The specimen showed more than $2 \mathrm{~cm}$ margin from the vascular tumour (figure 4). No adjuvant treatment was given to this patient.

\section{OUTCOME AND FOLLOW-UP}

The patient had a good recovery. The blood loss was $300 \mathrm{~cm}^{3}$ during the operation. Her liver function returned to normal 5 days after the surgery. She resumed a normal diet on day 3 and was discharged home 5 days after the hepatectomy. Although the pathology was in favour of a benign potential of the PEComa, patients was followed up at 3 month intervals by a contrast CT scan of the abdomen.

\section{DISCUSSION}

Perivascular epithelioid cell neoplasms formed a rare group of mesenchymal tumour probably arising from the perivascular

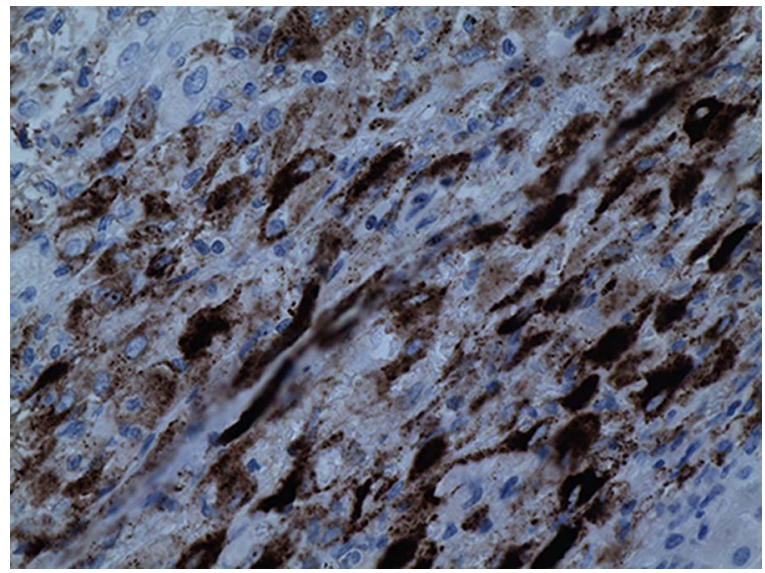

Figure 3 Immunohistochemical stain of the tumour showed positivity for human melanoma black 45 (HMN45) and Melan-A.

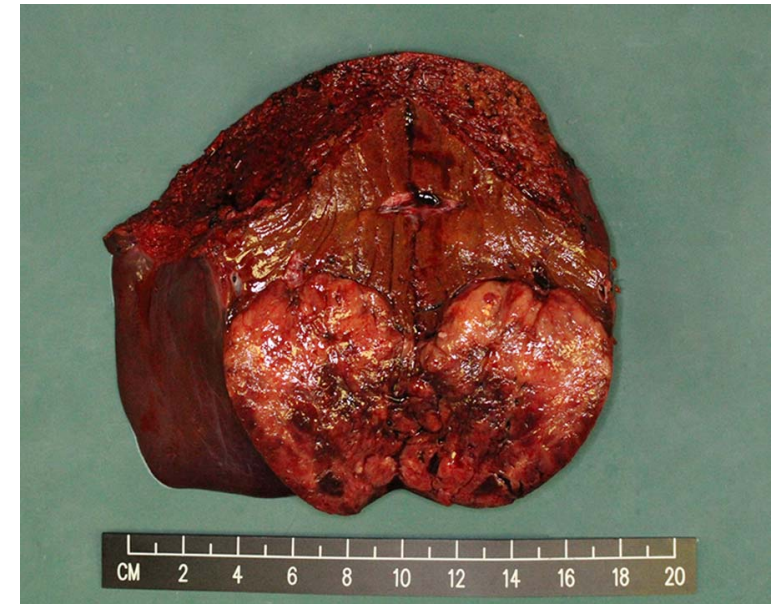

Figure 4 Specimen revealed a large tumour with a wide margin from the liver transection surface.

epithelioid cells throughout the body. ${ }^{1}$ This diagnosis has a relatively short history. The concept of perivascular epithelioid cells and its tumour classification was established in 2003 by the WHO. ${ }^{2}$ PEComa consisted of a range of lesion including angiomyolipoma, lymphangiomyomatosis, clear cell 'sugar' tumour of the lung and other lesions comprising perivascular epithelioid cells in soft tissues. ${ }^{3}{ }^{4}$ The urology system and the uterus are the more common sites of this condition. ${ }^{5}$ The incidence is higher in woman at the age of their 50s. PEComa is a disease that is associated with the tuberous sclerosis complex but can occur in normal individuals. ${ }^{7}$

The patient is usually asymptomatic until the lesion grows in size and cause localised pressure effect or stretching of the liver capsule. The lesion itself in not hormonal secreting and there is no serological markers for identification of this tumour. Contrast CT scan is the most common imaging modalities that detect this abnormality. For lesion with strong vascular component like this case, there will be vascular enhancement in the arterial phase and the lesion remained enhanced even in the delayed phase of the CT scan.

Clinically, it is difficult to differentiate a benign tumour from a malignant variant. However, it is suggested that, histological evaluation as well as size might provide valuable prognostic information. Tumour with a size larger than $5 \mathrm{~cm}$, mitotic count of more than 1 in the $\times 50$ high power fields and the presence of tumour cell coagulative necrosis are poor prognostic predictors for malignant PEComa. ${ }^{8} 9$

Resection of the lesion relieved the symptom of this patient and provided full histological evaluation as variant carrying malignant potential could occur. Even though there is no malignant feature in our current case, diligent follow-up with regular contrast CT scan should be carried out as the course of this disease is still largely unknown. Metastases are still possible despite there is no malignant features in the primary resected lesion. In case of metastasis, there has not been a consensus on the treatment modalities although surgery, radiotherapy, chemotherapy and targeted therapy have been suggested. ${ }^{10-13}$ There have been only 10 cases of PEComa of liver reported so far. Since this is a rare disease entity, documentation of the tumours presentation, investigation method, treatment modality, follow-up protocol and recurrence pattern is important to understand the nature history of this disease. 


\section{Learning points}

- Perivascular epithelioid cell neoplasms formed a rare group of mesenchymal tumour arising from the perivascular epithelioid cells throughout the body.

- Contrast CT scan usually showed a vascular tumour at the arterial and portal venous phases which may mimic hepatocellular carcinoma and haemangioma.

- Long-term follow-up is necessary even in patients where malignant features are absent as the natural history of this disease is not well documented.

\section{Competing interests None.}

Patient consent Obtained.

Provenance and peer review Not commissioned; externally peer reviewed.

\section{REFERENCES}

1 Hornick JL, Fletcher CD. PEComa: what do we know so far? Histopathology 2006; $48: 75-82$

2 Folpe AL, Kwiatkowski DJ. Perivascular epithelioid cell neoplasms: pathology and pathogenesis. Hum Pathol 2010;41:1-15.
3 Bonetti F, Pea M, Martignoni G, et al. Clear cell ('sugar') tumor of the lung is a lesion strictly related to angiomyolipoma - the concept of a family of lesions characterized by the presence of the perivascular epithelioid cells (PEC). Pathology 1994;26:230-6

4 Martignoni G, Pea M, Reghellin D, et al. PEComas: the past, the present and the future. Virchows Arch 2008;452:119-32.

5 Martignoni G, Pea M, Reghellin D, et al. Perivascular epithelioid cell tumor (PEComa) in the genitourinary tract. Adv Anat Pathol 2007;14:36-41.

6 Sukov WR, Cheville JC, Amin MB, et al. Perivascular epithelioid cell tumor (PEComa) of the urinary bladder: report of 3 cases and review of the literature. Am J Surg Pathol 2009;33:304-8.

7 Zeng JP, Dong JH, Zhang WZ, et al. Hepatic angiomyolipoma: a clinical experience in diagnosis and treatment. Dig Dis Sci 2010;55:3235-40.

8 Folpe AL, Mentzel T, Lehr HA, et al. Perivascular epithelioid cell neoplasms of soft tissue and gynecologic origin: a clinicopathologic study of 26 cases and review of the literature. Am J Surg Pathol 2005;29:1558-75.

9 Selvaggi F, Risio D, Claudi R, et al. Malignant PEComa: a case report with emphasis on clinical and morphological criteria. BMC Surg 2011;11:3.

10 Jeon IS, Lee SM. Multimodal treatment using surgery, radiotherapy, and chemotherapy in a patient with a perivascular epithelioid cell tumor of the uterus. J Pediatr Hematol Oncol 2005;27:681-4.

11 Parfitt JR, Bella AJ, Wehrli BM, et al. Primary PEComa of the bladder treated with primary excision and adjuvant interferon-alpha immunotherapy: a case report. $B M C$ Urol 2006;6:20.

12 Parfitt JR, Bella AJ, Izawa Jl, et al. Malignant neoplasm of perivascular epithelioid cells of the liver. Arch Pathol Lab Med 2006;130:1219-22.

13 Zekry N, Rettenmaier MA, Abaid LN, et al. Perivascular epithelioid cell neoplasms: a systematic review of prognostic factors. J Minim Invasive Gynecol 2009;16:527-32.

Copyright 2013 BMJ Publishing Group. All rights reserved. For permission to reuse any of this content visit http://group.bmj.com/group/rights-licensing/permissions.

BMJ Case Report Fellows may re-use this article for personal use and teaching without any further permission.

Become a Fellow of BMJ Case Reports today and you can:

- Submit as many cases as you like

- Enjoy fast sympathetic peer review and rapid publication of accepted articles

- Access all the published articles

- Re-use any of the published material for personal use and teaching without further permission

For information on Institutional Fellowships contact consortiasales@bmjgroup.com

Visit casereports.bmj.com for more articles like this and to become a Fellow 